Laporan Penelitian

\title{
Communication ability and related factors in children with hearing aids
}

\author{
Wijana, Rico Doloksaribu \\ Department of Otolaryngology-Head and Neck Surgery, \\ Faculty of Medicine, Universitas Padjadjaran/Hasan Sadikin Hospital, \\ Bandung
}

\begin{abstract}
ABSTRAK
Background: Hearing function is very significant in the development of speech and language. Hearing disorders in children can lead to communication skill disturbance. Hearing aids can help to support the development of hearing, talking, and communication abilities. Several factors such as age, duration of using hearing aids, and parental participation in encouraging children to communicate and undergo auditory verbal therapy, are recognized to have impacts on communication skills. Aim: To find out communication capabilities and related factors after using hearing aids in children. Method: A cross sectional study was performed at a private hearing center in Bandung. Inclusion criteria was children using hearing aids who were doing follow-up in the period January-May 2018. Result: From 60 research subjects, there were $35(58.33 \%)$ who used mixed communication, and $23(38.33 \%)$ were in special school. There were $37(61.67 \%)$ who had more than 6 hours communication, $45(75 \%)$ underwent routine therapy, and 23 (38.33\%) underwent Auditory Verbal Therapy (AVT) and Speech Therapy. The assessment was using PEACH (Parents' Evaluation of Aural/oral performance of Children) score. A total of $66.67 \%$ subjects had a low $(<60)$ PEACH score, $16.67 \%$ had a moderate $(>60-\leq 75)$ PEACH score, and $16.66 \%$ had a normal $(>75)$ PEACH score. The PEACH score in this study showed an average value of $52.63 \%$ with $16.66 \%$ had a normal $(>75)$ PEACH score. Conclusion: Specific characters that had significant correlation with normal PEACH score were communication method, educational method, communication duration, frequency of therapy, and type of therapy $(\mathrm{p}<0.05)$.
\end{abstract}

Keywords: PEACH score, hearing aid, communication, children

\begin{abstract}
Latar Belakang: Fungsi pendengaran sangat berpengaruh pada perkembangan bicara dan bahasa. Gangguan pendengaran pada anak dapat menyebabkan gangguan komunikasi. Alat bantu dengar menunjang mengembangkan kemampuan mendengar, berbicara, dan berkomunikasi. Beberapa faktor seperti usia, lamanya penggunaan alat bantu dengar, dan keaktifan orang tua dalam mendorong anak untuk berkomunikasi dan melakukan terapi verbal pendengaran diketahui memiliki dampak pada keterampilan komunikasi. Tujuan: Mengetahui kemampuan komunikasi dan faktor yang memengaruhi setelah menggunakan alat bantu dengar pada anak-anak. Metode: Telah dilakukan penelitian cross sectional di sebuah Klinik Pusat pendengaran di Bandung pada periode Januari-Mei 2018 . Kriteria inklusi untuk penelitian ini adalah anak yang menggunakan alat bantu dengar, yang melakukan kontrol pada periode Januari-Mei 2018. Hasil: Dari 60 subjek yang sesuai dengan kriteria penelitian, terdapat 35 anak (58,33\%) yang menggunakan komunikasi campuran, dan 23 anak (38,33\%) mengikuti pendidikan di sekolah khusus. Ada 37 anak (61,67\%) yang memiliki durasi komunikasi lebih dari 6 jam, 45 anak (75\%) rutin dalam terapi, dan 23 anak (38,33\%) yang menggunakan terapi Auditory Verbal Therapy (AVT) dan terapi wicara. Penilaiannya menggunakan skor PEACH (Parents' Evaluation of Aural/ oral performance of Children). Sebanyak 66,67\% subjek memiliki skor PEACH rendah $(<60), 16,67 \%$ memiliki skor PEACH sedang (> $60-\leq 75)$, dan 16,66\% memiliki skor PEACH normal (> 75). Skor PEACH dalam penelitian ini menunjukkan nilai rata-rata 52,63\% dengan 16,66\% memiliki skor PEACH normal (>75). Kesimpulan: Karakteristik yang memiliki hubungan yang signifikan dengan skor PEACH normal adalah metode komunikasi, metode pendidikan, durasi komunikasi, frekuensi terapi, dan jenis terapi yang digunakan $(p<0,05)$.
\end{abstract}


Kata Kunci : PEACH score, Alat Bantu Dengar, komunikasi, anak

Correspondence author: Rico Dolosaribu Fakultas Kedokteran Universitas Padjadjaran. Jln. Riung Hegar Raya No RIung Bandung. Bandung 40295. Email: dr.rico.icok@gmail.com

\section{INTRODUCTION}

Communication can be performed through auditory and visual pathways. The auditory pathway is characterized by speech and acoustic signs, while the visual path is carried out through lip reading and pragmatic signs, such as expression on the other person. ${ }^{1,2}$

The function of auditory perception includes awareness of sound and the ability to integrate with stimuli from other sensory organs as well as the ability to compare or distinguish sounds such as between mother's voice and father's voice. ${ }^{1,2,3}$ Role of hearing function in the speech process includes: 1 . the ability to hear the voice of conversation, causing someone to learn the language and to use it in their daily environment; 2 . the existence of a voice feedback channel (auditory feedback), that is the sound of the voice spoken by the speaker to his own ear. It can be beneficial for monitoring the sound pattern or words spoken, then it can be used to correct the state of the muscles of speech when the speaker is talking (motoric feedback). ${ }^{1,4}$

Talk is the ability to communicate in oral language which requires a harmonious combination of the neuromuscular system to produce phonation and sound articulation. The process of talking involves several systems and functions of the body, involving the respiratory system, cerebral cortex which is the central regulator of speech, the respiratory center in the brainstem, and the structure of articulation, oral resonance and nasal cavity. ${ }^{3}$

There are two processes of speaking, namely sensory and motoric processes.
Sensory aspects include the senses of hearing, sight and touch which function to understand what is heard, seen and felt. The motoric aspect is to regulate the larynx, articulation organs and resonance to produce sound. ${ }^{3}$

In the dominant hemisphere of the brain or central nervous system, Broadmann area 39 is a visuo-lexic perception center that controls the recognition and understanding of everything related to visual aspect of language. There are 2 centers that regulate the mechanism of language namely Wernicke area located in Broadmann areas 41 and 42 , which is the center of auditory-lexic perception that function in the recognition and understanding of everything related to verbal language, and the Broca area which is the expressive language center. The language centers then relate to one another which is called the association process. ${ }^{5,6}$

When we hear a conversation, the sound waves turn into electrical waves to the Wernicke area of the brain, and response to the conversation by conveying it to the motoric area in the brain that controls speech movements. Subsequently, the speech process which is produced by the vibration of the vocal cords transmitted to the oral and nasal cavities as sound resonance. Resonance is then formed into language articulation by the movement of the lips, tongue and palate. So the process of speech requires coordination of the sensory and motoric nervous systems, where it emphasizes that auditory organs are very important. ${ }^{4,6}$

Ability to speak is very important for every person, and had to be learned in the early days of life. As time passes, a child's ability to speak increases from one word (the 
average of six words in a day), becomes one sentence and then becomes a conversation. The language ability is a tool for social interaction and opens the opportunity for a child to learn, seek experience, fulfill needs, and grow normally and productively.,

Some of the factors that influence speech development: good form auditory pathways, auditory stimuli, surrounding environment, adults' participation in encouraging a child to speak, and the language used daily. According to Young and Kirk, ${ }^{7}$ there are 5 dominant factors in shaping the ability to speak i.e. social, perceptual, cognitive, conceptual, and linguistic factors.

The goal of amplification was different for young children and adult. For young children the hearing aids will facilitate the development of language, speech perception, and speech production, whereas for adults the goal of amplification is in adjusting with the surrounding environment (contextual and redundancy cues). ${ }^{9}$

Early identification of hearing problems and prompt effective treatment will provide the children a chance to develop language as good as their normal-hearing peers. For spoken language development, children need access to the full range of speech sounds during all waking hours, and daily hearing aid management. Parents should understand how hearing loss affects the development of their child, and they also need to know and apply the skill of hearing aid management (e.g., consistent use, listening checks, and troubleshooting problems). ${ }^{10}$

\section{METHODS}

A descriptive study had been conducted with inclusion criteria of children who used hearing aids and had been followed up in the period of January-May 2018. The researcher used PEACH (Parents' Evaluation of Aural/ oral performance of Children) score based on
13 questionnaire questions. The researcher conducted a face-to-face meeting with each subject's parents to explain about the meaning, purpose, and results to be achieved in each question item in order to obtain a correct understanding. Subject's parents then took home the questionnaire, observed the child's communication behavior for one week, and then the questionnaire was returned to the researcher. A final assessment test and a statistical analysis of the characteristics of communication skills were performed upon the collected questionnaires.

\section{RESULTS}

In the period of January - May 2018 a descriptive study had been conducted in a private hearing and speech center in Bandung. There were 65 children using hearing aids doing follow up during this period and the researcher obtained 60 subjects who were willing to take part in the study. The subjects' parents were provided with explanation of the procedures for filling in the $\mathrm{PEACH}$ questionnaire. The PEACH score in this study showed an average value of $52.63 \%$ with $16.66 \%$ had a normal PEACH score $(>75)$.

A total of $51.6 \%$ of the subjects were boys. Our finding was similar with a metaanalysis study conducted by Umek ${ }^{12}$ that girls expressed higher language ability than boys. Subjects resided outside of Bandung city were $39(51.6 \%)$. Total subjects fitted with hearing aids at the age between two to five years old were $61.7 \%$, and $48.3 \%$ of subjects had used hearing aids as long as one to three years. Prenatal risk factors were found in $89.8 \%$ subjects. Most subjects ( $88.3 \%$ ) had a hearing threshold of $>80 \mathrm{~dB}$ before wearing hearing aids, and $33.3 \%$ of subjects used unilateral hearing aid.

Mixed communication between verbal and non-verbal was used as means of daily communication by $58.33 \%$ of subjects, with $61.67 \%$ communicating with parents and 
Table 1.Subject distribution based on characteristics

\begin{tabular}{|c|c|c|c|}
\hline No & Characteristics & Frequency $(n=60)$ & Percent (\%) \\
\hline \multirow[t]{3}{*}{1} & Gender & & \\
\hline & Boy & 31 & 51.6 \\
\hline & Girl & 29 & 48.4 \\
\hline \multirow[t]{3}{*}{2} & Origin of the patient & & \\
\hline & Bandung & 29 & 48.4 \\
\hline & Beyond Bandung & 31 & 51.6 \\
\hline \multirow[t]{4}{*}{3} & Length use of hearing aid & & \\
\hline & $<1$ year & 9 & 15 \\
\hline & $1-<3$ years & 29 & 48.3 \\
\hline & $\geq 3$ years & 22 & 36.7 \\
\hline \multirow[t]{4}{*}{4} & Age of use hearing aid & & \\
\hline & $\leq 2$ years & 3 & 0.5 \\
\hline & $2-<5$ years & 37 & 61.7 \\
\hline & $\geq 5$ years & 20 & 33.3 \\
\hline \multirow[t]{4}{*}{5} & Risk factor & & \\
\hline & Prenatal & 53 & 89.8 \\
\hline & Perinatal & 4 & 6.8 \\
\hline & Postnatal & 3 & 3.4 \\
\hline \multirow[t]{8}{*}{6} & Right hearing threshold & & \\
\hline & $40-60 \mathrm{~dB}$ & 4 & 6.67 \\
\hline & $60-80 \mathrm{~dB}$ & 3 & 5.00 \\
\hline & $>80 \mathrm{~dB}$ & 53 & 88.33 \\
\hline & Left hearing threshold & & \\
\hline & $40-60 \mathrm{~dB}$ & 4 & 6.67 \\
\hline & $60-80 \mathrm{~dB}$ & 3 & 5.00 \\
\hline & $>80 \mathrm{~dB}$ & 53 & 88.33 \\
\hline \multirow[t]{3}{*}{7} & Ear side of hearing aid & & \\
\hline & Unilateral & 20 & 33.3 \\
\hline & Bilateral & 40 & 66.7 \\
\hline \multirow[t]{3}{*}{8} & Hearing aid system & & \\
\hline & Analog Programmable & 19 & 31.67 \\
\hline & Digital Programmable & 41 & 68.33 \\
\hline \multirow[t]{4}{*}{9} & Communication method & & \\
\hline & Verbal & 25 & 41.67 \\
\hline & Non-Verbal & 0 & \\
\hline & Mix & 35 & 58.33 \\
\hline \multirow[t]{4}{*}{10} & Education method & & \\
\hline & Not yet attended School & 22 & 36.67 \\
\hline & Public School & 15 & 25.00 \\
\hline & Special School & 23 & 38.33 \\
\hline \multirow[t]{3}{*}{11} & Communication duration & & \\
\hline & $\leq 6$ hours & 23 & 38.33 \\
\hline & $>6$ hours & 37 & 61.67 \\
\hline \multirow[t]{3}{*}{12} & Frequency of therapy & & \\
\hline & Routine & 45 & 75 \\
\hline & Not Routine & 15 & 25 \\
\hline \multirow[t]{3}{*}{13} & Education period of parents & & \\
\hline & $\leq 16$ years & 58 & 96.67 \\
\hline & $>16$ years & 2 & 3.33 \\
\hline 14 & Parents income & & \\
\hline & $<6$ Million & 35 & 58.33 \\
\hline & $6-15$ Million & 25 & 41.67 \\
\hline 15 & Type of hearing aids & & \\
\hline & swift $120+$ & 21 & 35 \\
\hline & SAF $300 \mathrm{SP}$ & 3 & 5 \\
\hline & $3000 \mathrm{DM}$ & 13 & 21.67 \\
\hline & RIA P & 1 & 1.67 \\
\hline & Dinamo Sp 4 & 2 & 3.33 \\
\hline & Dinamo Sp 6 & 3 & 5 \\
\hline & BTE P & 2 & 3.33 \\
\hline & Sumo DM & 13 & 21.67 \\
\hline & Get $P$ & 2 & 3.33 \\
\hline 16 & Therapy & & \\
\hline & Speech Therapy & 20 & 33.33 \\
\hline & AVT \&Speech Therapy & 23 & 38.33 \\
\hline & AVT & 14 & 23.33 \\
\hline & Not doing Therapy & 3 & 5.00 \\
\hline
\end{tabular}


ORLI Vol. 49 No. 2 Tahun 2019

Communication ability and related factors

Tabel 2.Relationship between characteristics and PEACH score

\begin{tabular}{|c|c|c|c|c|c|}
\hline \multirow[t]{2}{*}{ No } & \multirow[t]{2}{*}{ Characteristics } & \multicolumn{3}{|c|}{ Communication Ability (PEACH Score) } & \multirow[t]{2}{*}{$\mathbf{p}$} \\
\hline & & $\operatorname{Low}(n=40)$ & Medium (n=10) & $\operatorname{Normal}(n=10)$ & \\
\hline \multirow[t]{3}{*}{1} & Gender & & & & \\
\hline & Boy & $21(67.7 \%)$ & $4(12.9 \%)$ & $6(19.4 \%)$ & 0.659 \\
\hline & Girl & $19(65.5 \%)$ & $6(20.7 \%)$ & $4(13.8 \%)$ & \\
\hline \multirow[t]{4}{*}{2} & Age of using hearing aid & & & & \\
\hline & $\leq 2$ years & $2(100.0 \%)$ & $0(0.0 \%)$ & $0(0.0 \%)$ & 0.604 \\
\hline & $2-<5$ years & $11(78.6 \%)$ & $2(14.3 \%)$ & $1(7.1 \%)$ & \\
\hline & $\geq 5$ years & $27(61.4 \%)$ & $8(18.2 \%)$ & $9(20.5 \%)$ & \\
\hline \multirow[t]{4}{*}{3} & Length use of hearing aids & & & & \\
\hline & $<1$ year & $11(78.6 \%)$ & $2(14.3 \%)$ & $1(7.1 \%)$ & 0.733 \\
\hline & $1-<3$ years & $14(58.3 \%)$ & $5(20.8 \%)$ & $5(20.8 \%)$ & \\
\hline & $\geq 3$ years & $15(68.2 \%)$ & $3(13.6 \%)$ & $4(18.2 \%)$ & \\
\hline \multirow[t]{4}{*}{4} & Risk factor & & & & \\
\hline & Prenatal & $34(64.2 \%)$ & $9(17.0 \%)$ & $10(18.9 \%)$ & 0.524 \\
\hline & Perinatal & $4(100.0 \%)$ & $0(0.0 \%)$ & $0(0.0 \%)$ & \\
\hline & Postnatal & $2(66.7 \%)$ & $1(33.3 \%)$ & $0(0.0 \%)$ & \\
\hline \multirow[t]{4}{*}{5} & Right hearing threshold & & & & \\
\hline & Medium & $1(25.0 \%)$ & $1(25.0 \%)$ & $2(50.0 \%)$ & 0.133 \\
\hline & Heavy & $1(33.3 \%)$ & $0(0.0 \%)$ & $2(66.7 \%)$ & \\
\hline & Very Heavy & $38(71.7 \%$ & $9(17.0 \%$ & $6(11.3 \%)$ & \\
\hline \multirow[t]{4}{*}{6} & Left hearing threshold & & & & \\
\hline & Medium & $1(25.0 \%)$ & $1(25.0 \%)$ & $2(50.0 \%)$ & 0.276 \\
\hline & Heavy & $8(61.5 \%)$ & $2(15.4 \%)$ & $3(23.1 \%)$ & \\
\hline & Very Heavy & $31(72.1 \%)$ & $7(16.3 \%)$ & $5(11.6 \%)$ & \\
\hline \multirow[t]{3}{*}{7} & Ear side implants & & & & \\
\hline & Unilateral & $13(65.0 \%)$ & $5(25.0 \%)$ & $2(10.0 \%)$ & 0.357 \\
\hline & Bilateral & $27(67.5 \%)$ & $5(12.5 \%)$ & $8(20.0 \%)$ & \\
\hline \multirow[t]{3}{*}{8} & Hearing aid system & & & & \\
\hline & Analog & $14(73.7 \%)$ & $4(21.1 \%)$ & $1(5.3 \%)$ & 0.260 \\
\hline & Digital & $26(63.4 \%)$ & $6(14.6 \%)$ & $9(22.0 \%)$ & \\
\hline \multirow[t]{4}{*}{9} & Communication method & & & & \\
\hline & Verbal & $8(32.0 \%)$ & $7(28.0 \%)$ & $10(40.0 \%)$ & 0.000 \\
\hline & Non-Verbal & $0(0.0 \%)$ & $0(0.0 \%)$ & $0(0.0 \%)$ & \\
\hline & Mix & $32(91.4 \%)$ & $3(8.6 \%)$ & $0(0.0 \%)$ & \\
\hline \multirow[t]{4}{*}{10} & Education method & & & & \\
\hline & Not yet in School & $18(81.8 \%)$ & $2(9.1 \%)$ & $2(9.1 \%)$ & 0.000 \\
\hline & Public School & $3(20.0 \%)$ & $4(26.7 \%)$ & $8(53.3 \%)$ & \\
\hline & Special School & $19(82.6 \%)$ & $4(17.4 \%)$ & $0(0.0 \%)$ & \\
\hline \multirow[t]{3}{*}{11} & Communication duration & & & & \\
\hline & $\leq 6$ Hours & $23(100.0 \%)$ & $0(0.0 \%)$ & $0(0.0 \%)$ & 0.000 \\
\hline & $>6$ Hours & $17(45.9 \%)$ & $10(27.0 \%)$ & $10(27.0 \%)$ & \\
\hline \multirow[t]{3}{*}{12} & Frequency of therapy & & & & \\
\hline & Routine & $26(57.8 \%)$ & $9(20.0 \%)$ & $10(22.2 \%)$ & 0.036 \\
\hline & Not Routine & $14(93.3 \%)$ & $1(6.7 \%)$ & $0(0.0 \%)$ & \\
\hline \multirow[t]{3}{*}{13} & Education period of parents & & & & \\
\hline & $\leq 16$ years & $8(80.0 \%)$ & $0(0.0 \%)$ & $2(20.0 \%)$ & 0.301 \\
\hline & $>16$ years & $32(64.0 \%)$ & $10(20.0 \%)$ & $8(16.0 \%)$ & \\
\hline \multirow[t]{3}{*}{14} & Parents income & & & & \\
\hline & $<6$ Million & $24(68.6 \%)$ & $5(14.3 \%)$ & $6(17.1 \%)$ & 0.842 \\
\hline & 6 - 15 Million & $16(64.0 \%$ & $5(20.0 \%)$ & $4(16.0 \%)$ & \\
\hline 15 & Therapy & & & & \\
\hline & Speech Therapy & $18(90.0 \%)$ & $2(10.0 \%)$ & $0(0.0 \%)$ & 0.020 \\
\hline & AVT \& Speech Therapy & $15(62.5 \%)$ & $4(16.7 \%)$ & $5(20.8 \%)$ & \\
\hline & AVT & $4(30.8 \%)$ & $4(30.8 \%)$ & $5(38.5 \%)$ & \\
\hline & Not doing Therapy & $3(100.0 \%)$ & $0(0.0 \%)$ & $0(0.0 \%)$ & \\
\hline
\end{tabular}

Description : * Chi-square test, significant if $\mathrm{p}<0.05$. 
the surrounding environment for more than six hours per day, and $75 \%$ were having routine auditory verbal therapy, while $35 \%$ of subjects used swift 120+ type of hearing aids, which $68.33 \%$ of users utilised digital programmable. Most subjects (59.3\%) attended special schools, and $38.33 \%$ parents had undergone education $\leq 16$ years. As much as $58.33 \%$ of subjects' parents had an income between six to fifteen million per month. As the form of therapy, AVT and Speech Therapy was as much as $38.33 \%$.

Based on the correlation shown in table 2, out of 40 children who used mixed communication, there were $91.4 \%$ who had low PEACH score and $8.6 \%$ had medium PEACH score. Out of 23 children who went to special schools $82.6 \%$ had low PEACH score and $17.4 \%$ had medium PEACH score. Out of 37 children who had communication duration more than 6 hours per day, $45.9 \%$ had low PEACH score, $27 \%$ had medium PEACH score, and $27 \%$ had normal PEACH score. Out of 45 children who had routine therapy 57.8\% had low PEACH score, 20\% had medium PEACH score, and $22.2 \%$ had normal PEACH score. Out of 23 children who underwent AVT and Speech Therapy, $62.5 \%$ had low PEACH score, $16.7 \%$ medium $\mathrm{PEACH}$ score and $20.8 \%$ normal PEACH score.

\section{DISCUSSION}

A total of $51.6 \%$ of the subjects were male. Our study finding was in accordance with a meta-analysis study conducted by Umek, ${ }^{12}$ that girls expressed higher language ability than boys. Most subjects $(89.8 \%)$ had prenatal risk factors. It has been estimated that bilateral sensorineural hearing loss (SNHL) occurs in approximately 1.86 of 1000 newborns. The prevalence of bilateral severe SNHL was previously reported to be $9.7 \%$ in neonates who survived with a very low birth weight $(1500 \mathrm{~g})$ and $16.7 \%$ in neonates who survived after neonatal seizure. Although the prevalence of severe SNHL in very low birth weight or preterm neonates has decreased in the past decade, it still remains significant, ranging from $0 \%$ to $4 \% .{ }^{13}$ The majority of subjects were fitted with hearing aids between the age of two to five years $(61.7 \%)$, and $48.3 \%$ subjects had used hearing aid for between one to three years. As much as $38.33 \%$ parents had undergone education for $\leq 16$ years. Earlier fitting of hearing aids was not significantly associated with better outcomes, however, children with hearing loss should get early intervention prior to 6 months old. It is unreasonable to delay amplification until the child is capable of providing a comprehensive behavioral audiogram. ${ }^{9,10}$ Four predictors associated with better developmental outcomes for children using hearing aids, were 1) no additional disabilities, 2) female gender, 3) lesser degree of hearing loss, and 4) higher maternal education. Further research was necessary to better understand hearing aid use and the influence of consistent use towards developmental outcomes. ${ }^{10}$ Mixed communication between verbal and non-verbal was used as a mean of daily communication by $58.33 \%$ of subjects, this is not in accordance with the research conducted by Dunn ${ }^{14}$ which stated that children who used oral communication methods in daily activities had better articulation and word recognition compared to children with mixed communication. Most subjects (59.3\%) attended special schools. As much as $58.33 \%$ of subjects parents had an income between six to fifteen million per month and $38.33 \%$ had AVT and Speech Therapy. Subjects communicating with parents and the surrounding environment for more than six hours a day was as much as $61.67 \%$, and $75 \%$ of subjects were doing routine auditory verbal therapy. Subjects who routinely underwent auditory verbal therapy had better and statistically significant PEACH scores compared with subjects who did not routinely 
got auditory verbal therapy $(\mathrm{p}=0.0036)$. In this study, routine in undergoing auditory verbal therapy meant once a week therapy. Compliance with auditory verbal therapy was influenced by the economic ability and location of the parent's residence. Subjects who had parents with sufficient economic ability and living in large cities tended to be more routine in carrying out verbal auditory therapy. ${ }^{15}$ Dorman, ${ }^{16}$ in his research stated that routine auditory verbal therapy could improve receptive language skills and good language articulation. However, the intensity of therapy is not the dominant factor in influencing the auditory and speaking development in post-cochlear implantation children, because verbal auditory therapy without intensive interaction with the surrounding environment will produce unsatisfactory results.

Boucher-Jones, ${ }^{17}$ in his research stated that auditory verbal therapy has a role in the development of communication through the interaction of several factors i.e. family and the surrounding environment, therapist factors, and individual factors. When family factors, the surrounding environment and individuals are good, the role of verbal auditory therapy will be effective.

The PEACH score in this study showed an average value of $52.63 \%$, with $16.66 \%$ had a normal PEACH score $(>75)$. The factors that had significant correlation with normal PEACH score were communication method, educational method, communication duration, frequency of therapy, and type of therapy applied.

\section{DAFTAR PUSTAKA}

1. Katz J., Chasin M., English K., Hood J.L., Tillery K.L. Newborn Hearing Screening, Assessment of Hearing Loss in Children, Auditory Pathway Representations of Speech Sounds in Humans. In:Katz J., Chasin M., English K., Hood J.L., Tillery K.L. Handbook of Clinical Audiology. Philadelphia: Lippincott Williams Wilkins. 2015. p.439-75, 527-44.
2. Schramm B., Bohnert A., Keilmann A. Auditory, speech and language develop ment in young children with cochlear implants compared with children with normal hearing. Int J Pediatr Otorhino laryngol. 2010;74 (7). p.812-9.

3. Gelfand S.A. Essentials of Audiology. New York: Thieme. 2009. p.595.

4. Mitchell R.B., Pereira K.D.. Pediatric Otolaryngology for The Children St. Louis: Springer. 2009.

5. Leybaert J., LaSasso C.J. Cued speech for enhancing speech perception and first language development of children with cochlear implants. Trends Amplif. 2010;14(2). p.96-112.

6. Meinzen-Derr J., Wiley S., Creighton J., Choo D. Auditory Skills Checklist: clinical tool for monitoring functional auditory skill development in young children with cochlear implants. Ann Otol Rhinol Laryngol. 2007; 116(11). p.812-8

7. Young N.M., Kirk I.K. Pediatric Cochlear Implantation Learning and The Brain. Dalam Young N.M., Kirk I.K. "Speech Perception and Spoken Word Recognition in Children with Cochlear Implants". New York: Springer. 2016. p.145-61.

8. Archbold S., Harris M., O'Donoghue G., Nikolopoulos T., White A., Richmond H.L. Reading abilities after cochlear implantation: the effect of age at implantation on outcomes at 5 and 7 years after implantation. Int $\mathbf{J}$ Pediatr Otorhinolaryngol. 2008; 72(10). p.1471-8.

9. Stelmachowicz PG. Hearing Aid Outcome Measures for Children. J Am Acad Audiol. 1999; 10. p.14-25.

10. Munoz K.,Preston E.,Sydney H.Pediatric Hearing Aid Use: How Can Audiologists Support Parents to Increase Consistency? J Am Acad Audiol. 2014; 25. p.380-7.

11. Ching T.Y., Hill M. The Parents Evaluation of Aural/Oral Performance of Children (PEACH) scale: normative. 2007. 18(3). p.220-35.

12. Umek L., Fekonja-Peklaj U. Gender differences in children's language: A metaanalysis of Slovenian studies. 2017. p.97111.

13. Kim HS., Choi YB., Park J., Jung YE., Cho HS., Park HK. Maternal and Placental Factors Associated with Congenital Hearing Loss in Very Preterm Neonates. Pediatrics and Neonatology. 2017; 58. p.236-44. 
14. Dunn C.C., Walker E.A., Oleson J., Kenworthy M., Van Voorst T., Tomblin J.B., Ji H., Kirk KI., Mcmurray B., Hanson M., Gantz BJ. Longitudinal speech perception and language performance in pediatric cochlear implant users: the effect of age at implantation. Ear Hear. 2014;35(2). p.14860.

15. Sharma S., Bhatia K., Singh S., Lahiri A.K., Aggarwal A. Impact of socioeconomic factors on paediatric cochlear implant outcomes. International Journal of Pediatric Otorhinolaryngology. 2017;102. p.90-7.

16. Dornan D., Hickson L., Murdoch B., Houston T., Constantinescu G. Is AuditoryVerbal Therapy Effective for Children with Hearing Loss?The Volta Review. 2010. p.361-87.

17. Brennan-Jones C.G., White J., Rush RW., Law J. Auditory-verbal therapy for promoting spoken language development in children with permanent hearing impairments. Cochrane Database Syst Rev. 2014(3):CD010100. 